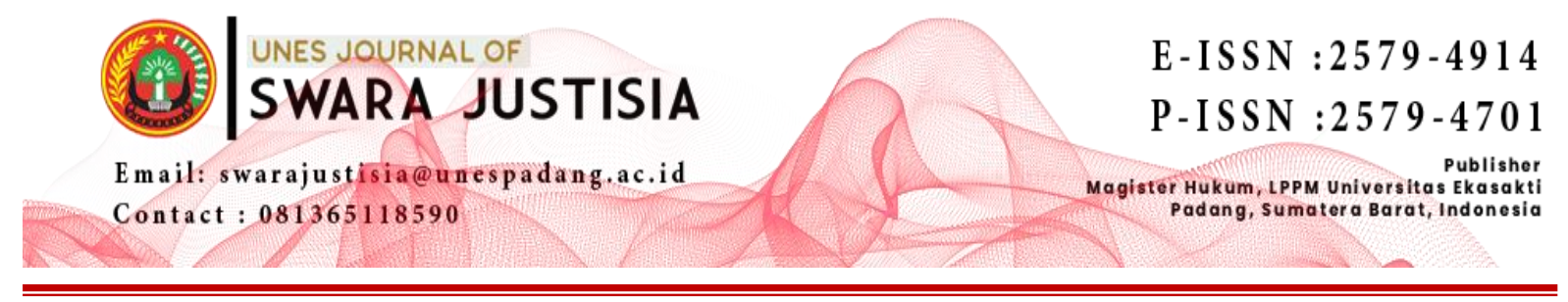

\title{
TAKTIK PENYIDIK DITRESKRIMUM POLDA SUMBAR DALAM MENGUNGKAP MODUS OPERANDI TINDAK PIDANA PENIPUAN OLEH TRAVEL BIRO PERJALANAN HAJI DAN UMROH
}

\author{
Firdaus Taufik \\ Program Magister Ilmu Hukum,Universitas Ekasakti, Padang \\ Email: firdaus.ipink02@gmail.com
}

\begin{abstract}
The tactics of the West Sumatra Police Ditreskrimum Investigator in Revealing the Modus Operandi of Fraud by the Hajj and Umrah Travel Bureau in the Police Report Number LP/50/II/2019/SPKT-Sbr, dated February 21, 2019 is to disguise yourself as if you are a consumer of the bureau. Hajj and Umrah trips. In the Police Report Number: LP/154/IV/2018/SPKT-Sbr, April 4, 2018 the investigator's tactics are by undercover, interviewing/interviewing the victim and related witnesses, as well as conducting research and document analysis related, whether the Hajj and Umrah Travel Bureau has permission from the Hajj and Umrah Travel Organizer (PPIU), which by conducting covert or secret interviews with witnesses before they are officially summoned as witnesses. The obstacle encountered by investigators at the West Sumatra Police Directorate of Criminal Investigation in Implementing Tactics to Reveal the Modus Operandi of Fraud by Travel Bureau Hajj and Umrah is the difficulty in finding the perpetrators who run away and the Directorate of Criminal Investigation does not have a Direction Finder (DF) tracking device. Difficulty finding evidence, namely a sign of the victim's transaction to the perpetrator of the fraud. Efforts to overcome these obstacles are to coordinate and use the Direction Finder (DF) tracking device and the Police to collaborate with related agencies such as the immigration office to find out passport information and the validity of the travel agency for prospective Umrah pilgrims.
\end{abstract}

Keywords: Crime, Fraud, Investigator, Investigation

\begin{abstract}
ABSTRAK
Taktik Penyidik Ditreskrimum Polda Sumbar Dalam Mengungkap Modus Operandi Tindak Pidana Penipuan Oleh Travel Biro Perjalanan Haji Dan Umroh pada Laporan Polisi Nomor LP/50/II/2019/ SPKT-Sbr, tanggal 21 Februari 2019 adalah dengan cara melakukan penyamaran seolah olah menjadi konsumen dari biro perjalanan haji dan umroh tersebut. Pada Laporan Polisi Nomor: LP/154/IV/2018/SPKT-Sbr, tanggal 4 April 2018 taktik penyidik adalahdengan cara melakukan penyamaran (undercover), wawancara/interogasi (interview) terhadap korban maupun saksi yang terkait, serta melakukan penelitian dan analisis dokumen yang terkait, apakah Biro Perjalanan Haji dan Umroh tersebut memiliki izin dari Penyelenggara Perjalanan Ibadah Haji dan Umroh (PPIU), yang mana dengan melakukan wawancara secara tersamar atau diam diam kepada saksi saksi sebelum secara resmi mereka dipanggil sebagai saksi. Kendala Yang Ditemui Penyidik Ditreskrimum Polda Sumbar Dalam
\end{abstract}


Melaksanakan Taktik Mengungkap Modus Operandi Tindak Pidana Penipuan Oleh Travel Biro Perjalanan Haji Dan Umroh adalah kesulitan dalam Mencari Pelaku yang Melarikan Diri dan Ditreskrimum tidak memiliki alat pelacak Direction Finder (DF). Kesulitan menemukan barang bukti yaitu tanda transaksi pihak korban kepada pelaku penipuan. Upaya mengatasi kendala tersebut adalah dengan melakukan koordinasi dan menggunakan alat pelacak Direction Finder (DF) serta Kepolisian melakukaan kerjasama dengan dinas terkait seperti kantor imigrasi untuk mengetahui informasi paspor dan keabsahan biro perjalanan para calon jamaah umroh.

Kata Kunci: Tindak Pidana, Penipuan, Penyidik, Penyidikan

\section{PENDAHULUAN}

Penegakan hukum di dalam sistem peradilan pidana bertujuan untuk menanggulangi setiap kejahatan. Tindakan negara harus dilandaskan ada aturan hukum yang berlaku.Hukum hendaknya dijadikan sebagai kerangka pijakan untuk mengatur dan menyelesaikan berbagai persoalan dalam menjalankan roda kehidupan bermasyarakat, berbangsa dan bernegara. KUHP memberi kewenangan-kewenangan hukum kepada negara melalui aparat penegak hukumnya untuk melakukan tindakan. Hal ini merupakan sumber kewenangan dan kekuasaan bagi berbagai pihak yang terlibat dalam proses ini (Polisi, Jaksa, Hakim, Penasehat Hukum). Hukum merupakan keseluruhan peraturan tingkah laku yang berlaku dalam suatu kehidupan bersama yang dapat dipaksakan dengan suatu sanksi. Pelaksanaan hukum dapat berlangsung secara formal dan damai, tetapi dapat juga terjadi karena pelanggaran hukum harus ditegakkan. ${ }^{1}$

Tindak pidana penipuan merupakan salah satu kejahatan yang mempunyai objek terhadap benda atau barang untuk dimiliki secara pribadi.Penipuan adalah suatu bentuk obral janji. Sifat umum dari obral janji itu adalah bahwa orang dibuat keliru, dan oleh karena itu ia rela menyerahkan barang atau uangnya. Kejahatan penipuan itu termasuk delik materil, dimana delik materil adalah delik yang perumusannya dititikberatkan kepada akibat yang tidak dikehendaki (dilarang). Delik ini baru selesai apabila akibat yang tidak dikehendaki itu telah terjadi. Kalau belum, maka paling banyak hanya ada percobaan. ${ }^{2}$

Merumuskan tindak pidana materil dimana akibat terlarang itu disebutkan secara tegas disamping unsur tingkah laku/perbuatan. Misalnya dalam penipuan, perbuatan adalah menggerakkan (bewegen) dan akibat terlarang adalah orang, a) menyerahkan benda, b) membuat utang, c) dan menghapuskan piutang. ${ }^{3}$ Dimana akibat terlarang itu tidak dicantumkan secara terpisah dengan perbuatan, melainkan telah terdapat pada unsur tingkah lakunya. ${ }^{4}$

Berdasarkan hal tersebut, jika ditinjau dari tujuan hukum, yang antara lain seperti yang dikemukakan di atas, akibat penipuan pihak tertipu dirugikan. Perbedaan kesalahan bukan hanya pada pihak penipu, melainkan pihak pemilik harta juga bersalah, yaitu karena kebodohannya, sehingga ia tertipu. Atas dasar itu sanksi yang dikenakan terhadap penipu

\footnotetext{
${ }^{1}$ Sudikno Mertokusumo, Mengenal Hukum Suatu Pengantar, Liberty, Yogyakarta, 2010, hlm 207

2 Isnu Gunadi W. Dan Jonedi Efendi, Cepat dan Mudah Memahami Hukum Pidana.: Prestasi Pustaka, Jakarta, 2011, hlm 52.

Adami Chazawi, Stelsel Pidana, Tindak Pidana, Teori-Teori Pemidanaan \& Batas Berlakunya Hukum Pidana, RajaGrafindo Persada, Jakarta, 2010, hlm 126.

${ }^{4}$ Ibid., hlm 127
} 
lebih ringan jika dibandingkan dengan pidana pencurian. Namun jika ditinjau dari sisi pelakunya, penipu lebih memiliki potensi psikis yaitu kepandaian, baik dalam kata-kata, maupun dalam bidang administrasi.

Permasalahan yang dibahas adalah taktik penyidik Ditreskrimum Polda Sumbar dalam mengungkap modus operandi tindak pidana penipuan oleh travel biro perjalanan haji dan umroh.

\section{METODE PENELITIAN}

Spesifikasi penelitian adalah deskriptif analitis, dengan metode pendekatan yuridis normative didukung oleh yuridis empiris. Jenis data yang digunakan adalah data sekunder dan data primer. Data sekunder diperoleh dari studi dokumen, data primer diperoleh dengan cara wawancara. Data yang diperoleh kemudian dianalisa secara kualitatif

\section{PEMBAHASAN}

\section{A. Taktik Penyidik Ditreskrimum Polda Sumbar Dalam Mengungkap Modus Operandi Tindak Pidana Penipuan Oleh Travel Biro Perjalanan Haji Dan Umroh}

Taktik penyidik untuk mengungkap bentuk modus operandi ini adalah dengan cara melakukan penyamaran seolah olah menjadi konsumen dari biro perjalanan haji dan umroh tersebut. Melalui penyamaran yang dilakukan penyidik mendapatkan alat bukti berupa surat surat yang berkaitan dengan perjalanan umroh yang ditawarkan oleh biro tersebut. Seperti Akta Pendirian Perusahaan biro travel haji dan umrah yang ternyata tidak memilki izin dari Penyelenggara Perjalanan Ibadah Haji dan Umroh (PPIU), surat pendaftaran sebagai peserta umroh, visa yang ternyata palsu dan lain sebagainya. Alat bukti surat yang ditemukan dari penyamaran ini terkadang sulit didapatkan secara langsung dari tersangka. Selain itu dalam penyamarannya penyidik juga menemukan rangkaian modus operandi dengan melakukan perekaman terhadap rangkaian kata bohong dan tipu muslihat yang dilakukan tersangka.

Travel PT. Grand Savire Holidays sengaja memberangkatkan jamaah dalam jumlah kecil sehingga ada tenggang waktu untuk dapat menggunakan uang yang ada untuk memberangkatkan jamaah yang terlebih dahulu mendaftar. Kerugian calon jamaah umrah mencapai Rp839,12 miliar. Angka tersebut belum termasuk biaya tambahan Rp2,5 juta yang diminta Travel PT. Grand Savire Holidays pada bulan Mei dengan dalih biaya carter pesawat. Travel PT. Grand Savire Holidays juga menawarkan paket Ramadhan dengan biaya tambahan Rp 3 juta hingga Rp 8 juta per jamaah. Total kerugian jamaah dengan dalih ini mencapai $\operatorname{Rp} 9,54$ miliar. $^{5}$

Modus Operandi yang digunakan oleh Travel PT. Grand Savire Holidays yaitu Travel PT. Grand Savire Holidays mengadakan seminar tentang perjalanan umrah. Yang kemudian mereka menawarkan tiga macam paket. Dimana paket pertama adalah paket yang disebut paket promo, kedua paket regular, dan ke tiga paket VIP.

Pada proses penyidikan Laporan Polisi Nomor: LP/154/IV/2018/SPKT-Sbr, taktik penyidik untuk menemukan modus operandinya adalah dengan cara melakukan penyelidikan berupa: penyamaran (undercover), Wawancara/interogasi (interview)

\footnotetext{
${ }^{5}$ Wawancara dengan penyidik pada Ditreskrimum Polda Sumbar pada tanggal 12 Juni 2021
} 
terhadap korban maupun saksi yang terkait, serta melakukan penelitian dan analisis dokumen yang terkait apakah Biro Perjalanan Haji dan Umroh tersebut memiliki izin dari Penyelenggara Perjalanan Ibadah Haji dan Umroh (PPIU). Wawancara dilakukan dengan menyamar seolah olah mencari informasi tentang biro travel umroh yang dapat dipercaya untuk mendaftar sebagai peserta umroh. Selanjutnya penyidik melakukan analisa dari hasil wawancara dan penelusuran alat bukti yang dilakukan. Berdasarkan taktik yang dilakukan didapat modus operandi penipuan yang dilakukan travel biro umroh tersebut dan terbukti bahwa biro travel tersebut tidak memiliki izin (ilegal).

Penipuan sendiri berasal dari kata tipu, yang berarti perbuatan atau perkataan yang tidak jujur, bohong, atau palsu dengan maksud untuk menyesatkan, mengakali,atau mencari untung. Sedangkan penipuan sendiri berdasarkan Kamus Besar Bahasa Indonesia merupakan proses, cara, atau perbuatan melakukan tipu, atau mengecoh kepada orang lain. ${ }^{6}$

Penipuan yang dilakukan oleh oknum yang tidak bertanggung jawab yang terhadap calon jamaah terutama kepada calon jamaah yang kurang jeli dalam memilih biro perjalanan. Penipuan terhadap penyelenggaraan ibadah umrah yang melanggar kewenangan dan penyalahgunaan hak, walaupun pemerintah telah mengeluarkan Undang-Undang Nomor 13 Tahun 2008 tentang Penyelenggaraan Ibadah Umroh yang telah berlangsung kurang lebih 4 tahun diberlakukannya, namun masih banyak biro perjalanan umrah yang melakukan penipuan kepada calon jemaah umrah.

Mengenai penipuan dan penggelapan dana umroh yang dilakukan oleh PT. Nazzam Tour \& Travel, dapat dikatakan bahwa modus operandi yang dilakukan oleh tersangka dalam melakukan aksi kejahatannya cukup rapi dan matang. Tersangka dalam hal ini memanfaatkan banyak biro penyelenggara perjalanan haji dan umroh untuk dijadikan sebagai target atau korban kejahatannya.

\section{B. Kendala Yang Ditemui Penyidik Ditreskrimum Polda Sumbar Dalam Taktik Mengungkap Modus Operandi Tindak Pidana Penipuan Oleh Travel Biro Perjalanan Haji Dan Umroh Dan Upaya Mengatasinya}

Kesulitan dalam Mencari Pelaku yang Melarikan Diri serta Ditreskrimum tidak memiliki alat Direction Finder (DF) yang berguna untuk mencari keberadaan pelaku dan selanjutnya berdasarkan hasil wawancara penulis dengan penyidik Ditreskrimum Polda Sumbar, mengatakan bahwa pemilik Travel PT. Grand Savire Holidays bukan asli warga Sumbar sehingga Penyidik Ditreskrimum Polda Sumbar kesulitan dalam mencari pelaku penyelenggara ibadah umrah.

Adapun dalam melakukan proses penyidikan yang dilakukan oleh Penyidik Ditreskrimum Polda Sumbar terhadap tersangka yaitu Biro Penyelenggara Perjalanan Haji dan Umrah ini ternyata belum maksimal. Penyidikan kurang maksimal karena lamanya pelaku ditemukan. Dalam proses penyidikan kasus tidak pidana penipuan calon jemaah umroh di Ditreskrimum Polda Sumbar terdapat 3 tahapan pemeriksaan, peninjauan tempat kejadian perkara, dan penyidikan. Pemeriksaan merupakan dasar penting dalam menyelesaikan suatu tindak pidana. Pemeriksaan dilakukan kepada calon

\footnotetext{
${ }^{6}$ S. Ananda, Kamus Besar Bahasa Indonesia, Kartika, Surabaya, 2009, hlm.364.
} 
tersangka dan saksi-saksi yang menguatkan suatu laporan dalam suatu tindak pidana. Berdasarkan hasil penelitian, pihak kepolisian telah melakukan pemeriksaan terhadap tersangka atas kasus penipuan para calon jamaah umroh terkait laporan korban dan saksisaksi. Pada kasus ini tidak dilakukan pemanggilan terlebih dahulu oleh pihak kepolisian terhadap para saksi-saksi karena saksi datang bersama korban yang selanjutnya dibuatkan berita acara pemeriksaan selaku saksi. Peninjauan Tempat Kejadian Perkara Peninjauan tempat kejadiaan perkara dilakukan setelah adanya keterangan kuat dari saksi-saksi dan pengakuan dari tersangka. Peninjauan tempat kejadian perkara ini terkait dengan lokasi dimana tersangka melakukan tindak pidana penipuan kepada para calon jamaah umroh yang dilakukan oleh tersangka.

Kendala lainnya adalah Tidak Terdaftarnya Travel Penyelenggara Ibadah Umrah Travel penyelenggara ibadah umrah milik pelaku ini tidak terdaftar di instansi terkait sehingga pihak penyidik kesulitan untuk melakukan penyidikan terhadap pelaku penipuan. Faktor Keabsahan Biro Perjalanan Biro jasa yang melayani penyelenggaraan perjalanan haji atau umroh juga harus selalu diawasi secara ketat oleh Pemerintah melalui kementerian terkait.Pada saat ini semakin banyak biro jasa yang menawarkan kemudahan-kemudahan dalam penyelenggaraan haji dan umroh yang tidak memiliki legalitas yang jelas dan terdaftar secara resmi.Hal ini menjadi celah bagi para pelaku tindak kriminal penyelenggaraan haji dan umroh di Sumbar. Pendataan secara terperinci dan koordinasi antara Dinas terkait dengan pihak kepolisian dapat menjadi solusi yang cukup baik untuk meminimalisir tindak pidana penipuan kepada para calon jamaah umroh di Sumbar. Koordinasi antara aparat kepolisian dengan pihak kantor imigrasi masih kurang terjalin dengan baik. Hal ini membuat penerbitan paspor dan segala bentuk perizinan para calon jamaah haji/umroh sering disalahgunakan oleh para pelaku tindak pidana penipuan calon jamaah umroh.

Kendala internal dalam pihak Ditreskrimum Polda Sumbar ini dapat diatasi dengan menambahkan sumber daya manusia, yakni penyidik pada unit yang sering terjadi penumpukan kasus. Cara tersebut dapat mengurangi beban unit yang sering terjadi penumpukan kasus, sehingga proses penyidikan dapat berjalan efektif dan tidak terjadi penumpukan kasus. Cara tersebut juga lebih efektif daripada melimpahkan kasus ke unit lain yang bukan fungsinya untuk melakukan penyidikan terhadap tindak pidananya tersebut.

Penyidik Ditreskrimum Polda Sumbar mempunyai tugas dalam proses penyidikan dalam pengungkapan tersangka tindak pidana penipuan tersebut. Penyidik ini dituntut untuk menegakan hukum dan menangkap para pelaku tindak pidana tersebut akan tetapi penyidik Kepolisian tersebut tidak bisa maksimal dalam melakukan penyidikan dikarenakan beberapa faktor yang menjadi hambatan yaitu diantaranya adalah kurangnya bukti dari korban dan saksi. Berdasarkan hasil wawancara dengan Penyidik Ditreskrimum Polda Sumbar, mengatakan bukti yang diberikan korban tidak cukup sehingga memperlambat proses penyidikan yang dilakukan oleh penyidik, dan selanjutnya hambatan yang ditemukan yaitu domisili puluhan para jemaah (korban) yang jauh dan tersebar dibeberapa wilayah Sumbar serta kurangnya kerjasama antara saksi korban dengan pihak kepolisian dalam upaya melakukan penyidikan tindak pidana penipuan yang dilakukan oleh Biro Penyelenggara Perjalanan Haji dan Umrah, 
Ditreskrimum Polda Sumbar menghadapi kendala terkait dengan kerjasama antara pihak saksi dengan pihak kepolisian pada saat proses penyidikan. Ketika polisi memberikan surat panggilan yang ditujukan kepada saksi untuk dimintai keterangan, tidak jarang saksi tersebut yang tidak memenuhi dengan berbagai alasan atau bahkan saksi tersebut sengaja keluar kota untuk menghindari panggilan tersebut.

Kurang jelasnya pembagian tugas antar unit di Ditreskrimum Polda Sumbar. Jika terjadi penumpukan kasus yang terjadi di salah satu unit maka kasus-kasus tersebut diserahkan ke unit lain yang menangani kasus lebih sedikit. Kurangnya koordinasi antar pihak kepolisian membuat informasi yang didapatkan aparat kepolisian saling tumpang tindih. Padahal informasi dari para korban dan saksi memiliki andil yang sangat besar pada tahap penyidikan. Hal ini menjadi kendala selanjutnya.

Faktor penyebab terjadinya penggelapan dan penipuan dana umroh oleh biro penyelenggara perjalanan ibadah umroh dibedakan dalam dua bentuk, yaitu internal pelaku dan eksternal pelaku. Faktor internal pelaku, yaitu adanya dorongan dalam diri tersangka untuk memenuhi hasrat (hawa nafsu) yang tidak terbatas dan ketidak mampuan tersangka meraih mimpinya dalam mencapai kesuksesan dan kekayaan dengan tetap mematuhi aturan hukum atau secara sah (legitimated means). Sedangkan faktor eksternal pelaku didorong oleh beberapa faktor, yaitu : meningkatnya Jumlah Jamaah Umroh di Indonesia sehingga dimanfaatkan menjadi peluang bisnis. Umroh menjadi gaya hidup (life style), sehingga komunitas umroh tidak lagi berasal dari kalangan atas, tetapi masyarkat menengah ke bawah. Karakter atau budaya masyarakat yang mudah percaya dan tergiur dengan iming-iming yang menguntungkan. Sistem Penyelenggara Haji Dan Umroh (PHU) yang belum baik dan Lemahnya Pengawasan Kementerian Agama Republik Indonesia.

Kebijakan pemerintah dalam mencegah dan menanggulangi terjadinya penipuan dan penggelapan dana calon jamaah umroh oleh biro penyelenggara perjalanan umroh, yaitu dengan membuat kebijakan baru dalam sistem penyelenggaraan haji dan umroh melalui Sistem Informasi Pengawasan Terpadu Umroh dan Haji.

Upaya mengatasi kendala dalam kesulitan menemukan tersangka adalah dengan pengungkapan pelaku tindak pidana penipuan calon jamaah umroh oleh Ditreskrimum Polda Sumbar dapat ditempuh polisi dengan cara : laporan informasi tindak pidana penipuan dari masyarakat dan penyamaran oleh anggota kepolisian untuk mengungkap identitas pelaku dan melakukan pemeriksaan kebenaran laporan penipuan calon jamaah umroh melalui identifikasi kebenaran. Upaya Lain yang dilakukan adalah melakukan koordinasi dan meminta bantuan dari Bareskrim Polri guna mencari keberadaan tersangka menggunakan alat pelacak Direction Finder (DF). Selanjutnya upaya lain berikutnya yaitu melakukan kerjasama aparat kepolisian dengan dinas terkait seperti kantor imigrasi untuk mengetahui informasi paspor dan keabsahan biro perjalanan para calon jamaah umroh serta pihak kelurahan domisili tersangka.

Upaya lainnya yang dilakukan oleh penyidik Ditreskrimum Polda Sumbar dalam mengatasi hambatan yang timbul dalam penyidikan tindak pidana penipuan Biro Penyelennggara Perjalanan Haji dan Umrah di Sumbar adalah dengan melakukan sosialisasi serta memberikan saran kepada masyarakat khususnya pelapor, bahwa sebaiknya ketika melaporkan suatu kejadian tindak pidana disertai dengan bukti yang 
cukup supaya Penyidik Ditreskrimum Polda Sumbar dapat memproses kasus tersebut dengan cepat.

\section{PENUTUP}

Pemerintah dapat meninjau ulang kembali peraturan peraturan terkait dengan perjalanan umrah sehingga dapat terhindar dari tindak pidana penipuan. Institusi Kepolisian dapat lebih mengoptimalkan potensi sumber daya manusia personel penyidik yang dapat melakukan penyidikan tindak pidana penipuan dengan sebaik mungkin.

\section{DAFTAR PUSTAKA}

Adami Chazawi, Stelsel Pidana, Tindak Pidana, Teori-Teori Pemidanaan \& Batas Berlakunya Hukum Pidana, Raja Grafindo Persada, Jakarta, 2010

Sudikno Mertokusumo, Hukum Suatu Pengantar, Liberty, Yogyakarta, 2010

Isnu Gunadi W. Dan Jonedi Efendi,Cepat dan Mudah Memahami Hukum Pidana.: Prestasi Pustaka, Jakarta, 2011

S. Ananda, Kamus Besar Bahasa Indonesia, Kartika, Surabaya, 2009 